\title{
Analysis of the Overall Development Strategy of Well-off Sports Based on the Construction of Harmonious Society
}

Yugang Cui

Zhengzhou Technical College, Zhengzhou 450121, Henan, China.

Abstract: Well-off sports is a form of social and cultural activities. At the moment of building a harmonious society, we need to grasp the advantages of building a harmonious society, develop well-off sports, and meet people's growing material and cultural needs. Based on this, this article discusses measures to promote the overall development of well-off sports under the background of building a harmonious society for reference.

Keywords: Harmonious Society; Well-off Sports; Development Countermeasures

Well-off sports is a staged form of sports that emerged in the process of building a well-off society in an all-round way in China. It is a general term for sports that adapts to the policy system and cultural system of a well-off society. It includes various sports content such as society and family. Due to the characteristics of industrialization and other aspects, the overall development of well-off sports will promote the construction of a harmonious society in our country. Therefore, it is very important to strengthen the research on the overall development of well-off sports.

\section{Analysis of factors affecting the overall development of well-off sports}

\subsection{Economic income factors}

The effective development of well-off sports is inseparable from the economy, which is one of the main factors affecting its development. Although China's economic development is relatively fast, China's population is large and the economic development levels of various regions are different. The per capita income gap of each professional group is very large, especially the gap between urban and rural economic income is more obvious. The overall development has brought adverse effects $^{[1]}$.

\subsection{Cultural and educational factors}

Cultural and educational factors include people's educational level (educational status) and sports awareness, among which the educational level also affects people's sports awareness. Under the influence of low education level and low cultural literacy, people's sports awareness is not strong. Sports awareness is the driving force for individuals to participate in sports activities, and weak sports awareness will inevitably hinder the development of China's well-off sports ${ }^{[2]}$.

\subsection{Sports facility factors}

The development of any sports activities requires sports facilities as a guarantee. Although a number of sports venues have been built in our country, they are affected by economic factors and urban construction. The area of the venue is small and the supporting facilities are not perfect. The demand is not conducive to the development of well-off sports $^{[3]}$.

Copyright $\odot 2020$ Yugang Cui

doi: $10.18686 /$ ahe.v4i10.2883

This is an open-access article distributed under the terms of the Creative Commons Attribution Non-Commercial License (http://creativecommons. org/licenses/by-nc/4.0/), which permits unrestricted non-commercial use, distribution, and reproduction in any medium, provided the original work is properly cited. 


\subsection{People's sports awareness factors}

Sports awareness boosts individuals' physical exercise. The strength of sports awareness also affects people's interest in sports activities and their enthusiasm for participation. According to relevant investigations, the sports awareness of Chinese residents is generally weak, especially some rural residents. They have a one-sided understanding of sports and even have misunderstandings. They simply believe that sports should be a matter of athletes, and has little to do with them. Some will actively participate in sports activities. Some rural residents think that they go out early and return late every day, and work is just to exercise. There is no need or time to participate in sports activities. In addition, there are some urban residents who do not have a strong sense of sports. They simply think that as long as they spare a little time to do a few exercises, they are participating in sports activities. They lack a comprehensive understanding of sports skills and cultural connotations. These ideological understandings the question made me ask that the development of well-off sports has been affected ${ }^{[4]}$.

\subsection{Social sports instructor factors}

When developing social sports, it is necessary to have professional sports instructors to guide people. The sports instructors should tell people about sports skills, how to exercise properly, and how to manage health. However, judging from the current situation, our country has insufficient talents in this area, lack of professional instructors to guide people in sports, and unable to play the role of well-off sports, which also hinders the development of well-off sports.

\section{Overall development countermeasures of well-off sports under the background of building a harmonious society}

\subsection{Increase publicity and strengthen the construction of well-off sports laws and regulations}

In the context of a harmonious society, to promote the development of well-off sports, it is necessary to increase the propaganda and education of related sports theoretical knowledge, so that people have a deep understanding and understanding of the concept of well-off sports and form correct sports concepts. To better implement well-off sports activities, it is inevitable to need the guidance of theoretical knowledge and the premise of theory and practice. No matter what kind of sports activities, it must be guided by theory. The same is true for well-off sports. Therefore, we must strengthen the research and discussion on the theoretical knowledge of well-off sports, strengthen the publicity and education of related theoretical knowledge, and let people realize the positive impact of well-off sports, so that they can participate in well-off sports more consciously. In addition, we must strengthen the construction of laws and regulations regarding well-off sports to provide institutional guarantees for the development of well-off sports. At present, our country's laws and regulations on well-off sports have not yet been established. Therefore, we must build a complete legal system and strengthen law enforcement to build a complete set of well-off sports laws and regulations that adapt to national conditions ${ }^{[5]}$.

\subsection{Unified leadership, centralized planning}

The overall stable development of well-off sports is directly related to the level of economic development. Therefore, in order to promote the overall development of well-off sports, we need to integrate all sectors of society to serve the development of well-off sports. Special institutions can be established to deal with the development of well-off sports. The problem can also give us the ability to help areas with relatively lagging economic development build well-off sports, and provide a guarantee for the overall development of well-off sports. Of course, in this process, we need to implement the unified leadership, especially to coordinate the relationship between absolute and relative. The absoluteness mentioned here means that the overall development goals and planning of well-off sports are absolute. The relativity means that in the process of insisting on unified leadership, each region can also adopt effective measures in accordance with the development of the region to promote better well-off sports.

The overall development of well-off sports includes people in various regions and regions. Therefore, we need to plan its development process to better promote the development and construction of well-off sports. Scientific planning includes the general goals of well-off sports development and goals at various stages. In short, it is the development of people in different areas of well-off sports development. Through scientific planning, we can understand well-off sports more clearly. The goals of each stage of development and the methods can be adopted. At the same time, it also allows us to timely understand the 
problems arising in the development of well-off sports, and adopt effective measures to solve the problems according to the actual development of well-off sports in various regions, so as to mobilize people's enthusiasm for participating in the construction of well-off sports ${ }^{[6]}$.

\subsection{Organization and implementation, inspection and evaluation}

Organizational facilities are the key to the healthy development of well-off sports. We can fully implement the content of well-off sports planning through scientific and effective organization and implementation. Under the leadership and help of relevant departments, start with the core content of well-off sports development, adopt effective methods, adopt corresponding measures according to the actual situation of each region in the specific implementation stage, and take various favorable factors that can promote the construction of well-off sports to be fully integrated, so that the well-off sports can be sustained and healthy development.

In the development process of well-off sports construction, inspection and evaluation are also very important content, which affects the quality of well-off sports construction. Therefore, relevant departments need to arrange for experts to conduct comprehensive inspections on the construction of well-off sports on a regular basis, and conduct accurate assessments to find out the problems that exist and adopt effective measures to solve them. At the same time, after inspection and evaluation, it is possible to share the successful construction experience of well-off sports with all regions, and each region can learn from each other and communicate with each other, and serve to promote the overall development of well-off sports.

\subsection{Speed up the training of well-off sports talents and improve the diversified service system}

The development of well-off sports is inseparable from professional sports talents. Therefore, we need to recruit talents from multiple channels, improve the system of talent introduction and training, and invest more talents in the construction of well-off sports. In addition, a sound diversified service system must be established. A sound service system is the key to the healthy development of well-off sports. Through a perfect service system, it can solve the problems that arise in spontaneous well-off sports activities and integrate advantageous sports advantages. Enhance the enthusiasm of grassroots well-off sports organizations by building a training system.

\section{Conclusion}

A harmonious society is a new social form developed on the basis of a well-off society. The construction of a harmonious society provides conditions for the development of well-off sports, and the healthy development of efficiency sports will also promote the construction of a harmonious society in China. The two are Mutual influence and interaction. Therefore, in the context of building a harmonious society, we must attach importance to the construction of well-off sports and adopt effective measures to promote the overall development of well-off sports.

\section{References}

1. Zhao Y, Zhang S. Research on the development strategy of harmonious rural sports in Tianjin under the background of comprehensively building a well-off society. Management Observation 2018; 2(08): 153-154.

2. Zhu Q, Jin H. Analysis of the characteristics and era connotation of well-off sports in a harmonious society. Journal of Shandong Institute of Physical Education 2018; 10(22): 323-421.

3. Zhao S, Liu W. Research on the development of well-off sports under the background of building a harmonious society. Sports Science and Technology Literature Bulletin 2018; 6(05): 139-311.

4. Li H. Harmonious development of regional sports in Hunan Province in the construction of a well-off society. Exploratory Science 2017; 10(02): 429-651.

5. Su Z. Research on the development strategy of mass sports based on the transition period of harmonious society. Hebei Vocational Education 2017; 10(05): 109-215.

6. Ma J, Luo X. Countermeasures and suggestions for developing social sports and building a harmonious society[J]. Management Observation 2018; 6(13): 322-435. 